\title{
Effects of fresh and digested cowdung and poultry litter on the growth and yield of cabbage (Brassica oleracea)
}

\author{
M. S. Shahariar*, M. Moniruzzaman, B. Saha, G. Chakraborty, M. Islam and S.Tahsin \\ Laboratory of Soil and Environment, Biological Research Division, Bangladesh Council of Scientific and \\ Industrial Research (BCSIR), Dhanmondi, Dhaka-1205, Bangladesh
}

\begin{abstract}
A field experiment was conducted during Rabi season in the experimental field of BCSIR to see the effects of fresh and digested cowdung (CD) and poultry litter (PL) bio-slurry on the growth and yield of cabbage (Brassica oleracea). The experiment was laid in a Randomized Complete Block Design (CRBD) with six different treatments including control. Cabbage variety Atlas-70 was transplanted at the age of 35 days and was harvested at 120 days. Plant height, circumference, marketable weights and whole plant weight were examined to perceive the effects on the growth and yield of cabbages. The experiment revealed that both digested PL and CD bio-slurry had a significant effect $(\mathrm{P}<0.01)$ on the growth and yield components of cabbage. Increased plant growth and yield were in the order of digested PL bio-slurry $>$ digested CD bio-slurry $>$ fresh PL $>$ fresh CD in combination with recommended dose of fertilizers (RDF). Among the treatments, the highest head yield of cabbage $\left(97.6 \mathrm{t} \mathrm{ha}^{-1}\right)$ was obtained from RDF $+5 \mathrm{t} \mathrm{ha}^{-1}$ digested PL bio-slurry which was $366 \%$ higher than the control.
\end{abstract}

Keywords: Bio-slurry; Digested; Cowdung; Poultry litter; Yield; Cabbage

\section{Introduction}

Cowdung, poultry litter, water hyacinth and other biomass wastes are widely used to produce biogas which is potential renewable energy alternative in rural areas of Bangladesh. More than 30,000 biogas plants of varying gas-producing capacities run with cowdung and poultry litter for domestic purposes. These biogas plants generate more than 200,000 tones of bio-slurry on dry weight basis (Islam, 2006). Bioslurry, released from hydraulic chamber of bio-gas plant is anaerobically decomposed organic material of cowdung, poultry litter, water hyacinth, human excreta and other organic wastes. No effective program has been undertaken to use bio-slurry in agriculture. Although digested cowdung bio-slurry has a low content of $\mathrm{N}, \mathrm{P}$ and $\mathrm{K}$ as compared to chemical fertilizers, it is a valuable source of humus substance (Gaur et. al., 1984). Preliminary investigations show that both cowdung and poultry litter bio-slurry contain considerable quantities of plant nutrients, which may be used to improve soil fertility and thus the use of chemical fertilizers can be reduced to a great extent. Poultry litter bio-slurry is especially suitable for acid soils as it has strong liming effect. It reduces the acidity of the soils and thereby protects crops from aluminium toxicity. These organic fertilizers can effectively be utilized for organic farming for high value crops that is the demand of the day in Bangladesh and elsewhere.

The organic matter content as well as the fertility status of Bangladesh soil is low. Now it is well agreed that depleted soil fertility is a major constraint for higher crop production in Bangladesh and indeed, yield of several crops are declining in some soils (Bhuiyan, 1991). Maintenance of soil fertility is a prerequisite for long term sustainable agriculture and it is certain that organic manure (cowdung, poultry manure and their slurry) can play a vital role in the sustainability of soil fertility and crop production. Bio-slurry organic fertilizer contains 20-30\% more nutrients than commonly used organic fertilizers such as cowdung, duck and poultry manure, farmyard manure and compost as it is especially produced from biogas plants. This fertilizer also contains heavy metals much below acceptable limit. Bio-slurry may be used raw or after air drying to fertilize agricultural land.

Anaerobically digested bio-slurry contains more plant nutrient than aerobically decomposed cowdung and poultry manure. So, it is imperative to evaluate cowdung and poultry manure and their bio-slurry and slurry compost as a source of organic manure. Use of cowdung and poultry manure along with inorganic fertilizer should be the common practice for sustainable crop production and maintaining soil fertility. This may take care of maintaining good physical condition of soil and balancing other macro and micro-elements needed by plant. The beneficial effects of organic manure in vegetable production have been demonstrated by many workers (Robin, 1994; Singh et. al., 1970 and Subhan 1991). Balanced fertilization is prerequisite for exploiting optimum yield potentials of high yielding vegeta-

*Corresponding author. e-mail: shayeb.shahariar@gmail.com 
bles varieties. The present investigation with cabbage (Brassica oleracea) was undertaken to evaluate the effect of anaerobically digested cowdung and poultry litter bio-slurry in combination with recommended dose of inorganic fertilizers and compare it with the efficiency of undigested cowdung and poultry litter.

\section{Materials and methods}

The field experiment was conducted during Rabi season of 2009 at BCSIR experimental field to see the effects of cowdung and poultry litter (both before and after digestion) on the growth and yield of cabbage. The experiment was set up in a Randomized Complete Block Design (CRBD) with six different treatments and three replications of each treatment (Fig. 1). Six different treatments were: $T_{1}$ - Soil test based inorganic fertilizer (RDF); $\mathrm{T}_{2}-\mathrm{RDF}+5 \mathrm{tha}^{-1} \mathrm{CD}$ (fresh); $\mathrm{T}_{3}$ - RDF $+5 \mathrm{t} \mathrm{ha}^{-1} \mathrm{CD}$ bio-slurry (after digestion); $\mathrm{T}_{4}-\mathrm{RDF}+$ $5 \mathrm{t} \mathrm{ha}^{-1} \mathrm{PL}$ (fresh); $\mathrm{T}_{5}-\mathrm{RDF}+5 \mathrm{t} \mathrm{ha}^{-1} \mathrm{PL}$ bio-slurry (after digestion); $\mathrm{T}_{6}-$ Native fertility (absolute control). There were a total ( 6 treatments $\times 3$ replications) of 18 plots each having an area of $2 \mathrm{~m} \times 2 \mathrm{~m}$. Digested cowdung and poultry litter bio-slurry (end products that are released from a biogas chamber after anaerobic decomposition) were collected from the biogas plant situated at the Institute of Fuel Research and Development, BCSIR Dhaka. Fresh cowdung and poultry litter were also collected from the same source. Both fresh and digested cowdung and poultry litter were taken to the field of BCSIR and they were air dried for several days and were ground before field application. Both digested and fresh cowdung and poultry litter were incorporated with the soil during land preparation. Fertilizers were applied as per treatment based on soil analysis and Recommended Dose of Fertilizers (RDF) according to Fertilizer Recommended Guide 2005 (BARC, 2005). Amount of nutrients applied as per RDF during cultivation of cabbage (Brassica oleracea) are shown in Table I. Urea, TSP, MP, Gypsum and Boric acid were used as a source of $\mathrm{N}, \mathrm{P}, \mathrm{K}, \mathrm{S}$ and $\mathrm{B}$ respectively. Whole amount of P, K, S, B, cowdung, poultry litter and $1 / 3$ of $\mathrm{N}$ were applied at the time of final land preparation and remaining $2 / 3$ of $\mathrm{N}$ was applied in two equal installments at 20 and 45 days after planting. Equal sized healthy cabbage seedlings (Atlas-70 variety) of 35 days were transplanted on October 24 and 25, 2009 with a spacing of $60 \mathrm{~cm}$ from line to line and $45 \mathrm{~cm}$ from plant to plant within a line. Cabbages were harvested at 120 days after sowing by uprooting from the soil. For harvesting, 5 plants were selected randomly from each plot considering the boarder effect. Plant height, circumference, marketable weights and whole plant weight were taken at the field after harvesting.
Table I. Amount of nutrients applied as per Recommended Dose of Fertilizers (RDF) during cultivation of cabbage (Brassica oleracea)

\begin{tabular}{lccccc}
\hline Yield goal $\left(\mathrm{t} \mathrm{ha}^{-1}\right)$ & \multicolumn{5}{c}{ Nutrients applied as per RDF $\left(\mathrm{kg} \mathrm{ha}^{-1}\right)$} \\
\cline { 2 - 6 } & $\mathrm{N}$ & $\mathrm{P}$ & $\mathrm{K}$ & $\mathrm{S}$ & $\mathrm{B}$ \\
\hline $\begin{array}{l}\text { High yield goal } \\
(80 \pm 8)\end{array}$ & 126 & 50 & 14 & 16 & 0.5 \\
\hline
\end{tabular}

Source: Fertilizer Recommendation Guide, BARC 2005
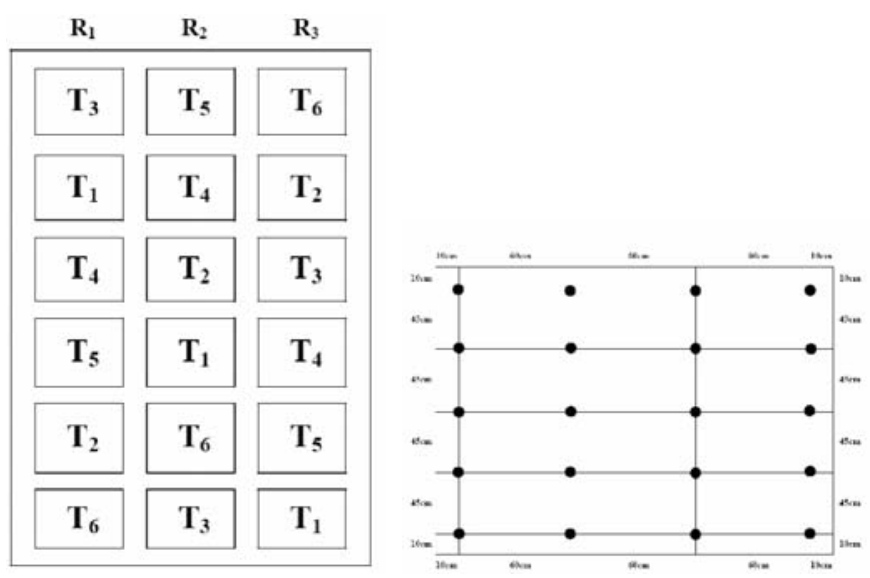

Fig. 1. Layout of the experimental field

*T- represents Treatmens *R-represents Replications/Blocks

Collection and preparation of soil and bio-slurry for laboratory analysis

Before initiation of the experiment, the soil samples representing $0-15 \mathrm{~cm}$ depth from surface of the experimental field were collected by composite soil sampling method as suggested by the soil survey staff of the USDA (1951). The soil samples were scraped from top to bottom with the help of an augur and mixed thoroughly. Collected soil samples were put in polythene bags, tagged with rubber band and labeled. Bio-slurry of cowdung and poultry litter were collected from the bulk amount that were applied in the experimental field in dried state and were put in polythene bags, tagged with rubber band and labeled. The collected soil samples were dried in air for 3 days by spreading on a thin layer of plastic paper. Visible roots and debris were removed from the soil sample and discarded. Ground samples of soil were screened to pass through a $2 \mathrm{~mm}$ stainless still sieve. The sieved samples were then mixed thoroughly for making the composite sample. Soil samples were preserved in plastic containers and labeled properly. The soil sample was used for various physical analyses. Another portion of the soil samples was screened to pass through a $0.5 \mathrm{~mm}$ sieve. The sieved sample were mixed thoroughly for making composite samples and preserved in the same way as above. These soils were used 
for chemical and physicochemical analyses. For the chemical analysis of bio-slurry, the sample preparation followed the same procedure as for soil samples.

\section{Laboratory analysis}

For the determination of moisture content $10 \mathrm{gm}$ of each of the fresh soils and bio-slurry were weighed and dried at 100 ${ }^{\circ} \mathrm{C} \pm 5{ }^{\circ} \mathrm{C}$ for 48 hours. The moisture content of soil was determined from the difference in weights of the wet soil, and the dry soil and the results were calculated on the basis of dry weight. $\mathrm{pH}$ of the soil and organic sample was determined using a digital $\mathrm{pH}$ meter at a soil/organic sample : water ratio of $1: 2.5$ according to method described in Thomas (1996). Carbon content in soil and bio-slurry were determined by the chromic acid digestion method of Walkley and Black as reported by Sparks (1996). The total Nitrogen (N) was determined by Macro Kjeldahl digestion method according to Bremner (1996). The distillation of digested samples was done with $40 \% \mathrm{NaOH}$ and the distillate was collected on a $4 \%$ Boric acid with mixed indicator. The distillate was titrated against $\mathrm{N} / 100 \quad \mathrm{H}_{2} \mathrm{SO}_{4}$. Available Phosphorous (P) in the soil sample was extracted by Bray and Kurtz method as described by Kuo (1996). Phosphorus (P) content of the soil and bio-slurry was determined colorimetrically in a UV-VIS spectrophotometer at $420 \mathrm{~nm}$ by vanadomolybdophosphoric yellow color method in nitric acid system (Jackson, 1962). Both available and total Sulfur (S) contents were determined by turbidimetric method with $\mathrm{BaCl}_{2}$ and Tween-80 reagent (Huq and Alam, 2005). Water soluble Boron (B) of the experimental soil was determined by spectrophotometer at $540 \mathrm{~nm}$ by using curcumin reagent (MoA, 2003). Calcium (Ca), Magnesium (Mg), Potassium $(\mathrm{K})$ of the soil from experimental field was extracted with neutral normal ammonium acetate buffer according to Helmke and Sparks (1996). Exchangeable K was determined using Flame Photometer and exchangeable $\mathrm{Ca}$ and $\mathrm{Mg}$ by Atomic Absorption Spectrophotometer (AAS). Fe and Mn content was determined by Atomic Absorption Spectrophotometer (AAS) by digesting $1 \mathrm{gm}$ of the soil sample and bio-slurry sample ( $<2 \mathrm{~mm}$ fraction) in 1:1 mixture of concentrated nitric and perchloric acids by heating the mixture in a fume cupboard and heated to dryness (Ure, 1990). The mixture was finally filtered by Whatman No. 40 filter paper and made to a certain volume by distilled water. The resultant extracts were analyzed for $\mathrm{Fe}$ and $\mathrm{Mn}$ using AAS (APHA-AWWA-WPCF, 1980). The nitric and perchloric acid digested aliquot of bio-slurry was used to determine total Phosphorous, Potassium, Sulfur, Calcium, Magnesium, Iron and Manganese content.

\section{Statistical Analysis}

All measured data were subjected to analysis of variance (ANOVA) using statistical software Sigma Plot (version
11.0) following the experimental design. As test criterion for looking differences between means the $\mathrm{LSD}_{0.01}$ was used (Gomez and Gomez, 1976).

\section{Results and discussion}

Representative soil sample from the experimental field was analyzed in the laboratory before setup of the experiment to see the nutrient status of the experimental soil. Nutrient status of the experimental soil is presented in the Table II.

Table II. Nutrient status of soils from the experimental field

\begin{tabular}{lc}
\hline Parameters & Value \\
\hline $\mathrm{pH}$ & 6.2 \\
Organic Matter (OM) & $1.14 \%$ \\
Total Nitrogen (N) & $0.062 \%$ \\
Calcium (Ca) & $680 \mathrm{mg} \mathrm{kg}^{-1}$ \\
Magnesium (Mg) & $192 \mathrm{mg} \mathrm{kg}^{-1}$ \\
Potassium (K) & $39.9 \mathrm{mg} \mathrm{kg}^{-1}$ \\
Phosphorous (P) & $12 \mathrm{mg} \mathrm{kg}^{-1}$ \\
Sulfur (S) & $11 \mathrm{mg} \mathrm{kg}^{-1}$ \\
Boron (B) & $0.19 \mathrm{mg} \mathrm{kg}^{-1}$ \\
Copper (Cu) & $5 \mathrm{mg} \mathrm{kg}^{-1}$ \\
Iron (Fe) & $127 \mathrm{mg} \mathrm{kg}^{-1}$ \\
Manganese (Mn) & $41 \mathrm{mg} \mathrm{kg}^{-1}$ \\
Zinc (Zn) & $2.09 \mathrm{mg} \mathrm{kg}^{-1}$ \\
\hline
\end{tabular}

Collected cowdung, poultry litter and effluents (bio-slurry) of cowdung and poultry litter from anaerobic digestion systems of biogas plants used for the experiment were also analyzed for their nutrient status (Table III).

Plant height, circumference, marketable weights and whole plant weight of cabbage (Brassica oleracea) were taken into consideration to see the effect of different fertilizer treatments on the growth and yield of cabbage. The mean head yield and yield attributes like plant height, circumference, whole plant weight and marketable weight of cabbages were significantly influenced by different fertilizer treatments.

\section{Plant height}

Mean plant height of cabbage was found to be affected significantly by the type of fertilizer treatments applied (Fig. 2). The mean plant height of cabbage grown on soil treated with digested CD and PL bio-slurry were found to be significantly different from the control plants $(\mathrm{P}<0.01)$. Highest mean plant height $(46.2 \mathrm{~cm})$ of cabbage was obtained from treatment $\mathrm{T}_{5}$ i.e. $\mathrm{RDF}+5 \mathrm{t} \mathrm{ha}^{-1}$ digested PL bio-slurry and the mean lowest plant height $(19.7 \mathrm{~cm})$ was obtained from native fertility (Fig. 2). In case of soil test based inorganic fertilizer application $\left(\mathrm{T}_{1}\right)$ the mean plant height was 39.9 
Table III. Nutrient status of fresh and digested cowdung and poultry litter used in the field experiments

\begin{tabular}{lcccc}
\hline Parameter & \multicolumn{2}{c}{ Cowdung $(\mathrm{CD})$} & \multicolumn{2}{c}{ Poultry litter (PL) } \\
\cline { 2 - 5 } & Fresh & Digested & 7.61 & Digested \\
\hline $\mathrm{pH}$ & 7.39 & 7.48 & $16.69 \%$ & 7.69 \\
Moisture & $17.90 \%$ & $18.52 \%$ & $1.22 \%$ & $18.44 \%$ \\
Nitrogen & $1.16 \%$ & $1.55 \%$ & $2.01 \%$ & $1.95 \%$ \\
Phosphorus & $0.86 \%$ & $1.89 \%$ & $0.88 \%$ & $3.14 \%$ \\
Potassium & $0.89 \%$ & $1.04 \%$ & $0.75 \%$ & $1.12 \%$ \\
Sulfur & $0.51 \%$ & $0.81 \%$ & $2.25 \%$ & $1.01 \%$ \\
Calcium & $0.74 \%$ & $0.98 \%$ & $0.75 \%$ & $3.45 \%$ \\
Magnesium & $0.28 \%$ & $0.33 \%$ & $0.125 \%$ & $0.88 \%$ \\
Iron & $0.089 \%$ & $0.105 \%$ & $345 \mathrm{mg} \mathrm{kg}^{-1}$ & $0.195 \%$ \\
Manganese & $445 \mathrm{mg} \mathrm{kg}^{-1}$ & $835 \mathrm{mg} \mathrm{kg}^{-1}$ & & $697 \mathrm{mg} \mathrm{kg}^{-1}$ \\
\hline
\end{tabular}

$\mathrm{cm}$ which was lower than the treatment along with cowdung, poultry litter and their bio-slurry. Between the digested and fresh sources, digested sources gave better results. Again, among the two sources, poultry litter performed better than the cowdung.

The number of unfold leaves of each cabbage plant were also recorded during harvest time. The highest number of unfold leaves per plant was recorded at native fertility i.e. treatment $\mathrm{T}_{6}$. Applied treatments appeared to have significant $(\mathrm{P}<$ 0.01 ) influence in reducing unfolded leaves of cabbages. The lowest number of unfolded leaves per plant (average 10 leaves per plant) of cabbages were recorded for treatment $T_{5}$ (RDF $+5 \mathrm{tha}^{-1}$ digested PL bio-slurry) which was close to treatment $\mathrm{T}_{3}\left(\mathrm{RDF}+5 \mathrm{tha}^{-1}\right.$ digested $\mathrm{CD}$ bio-slurry).

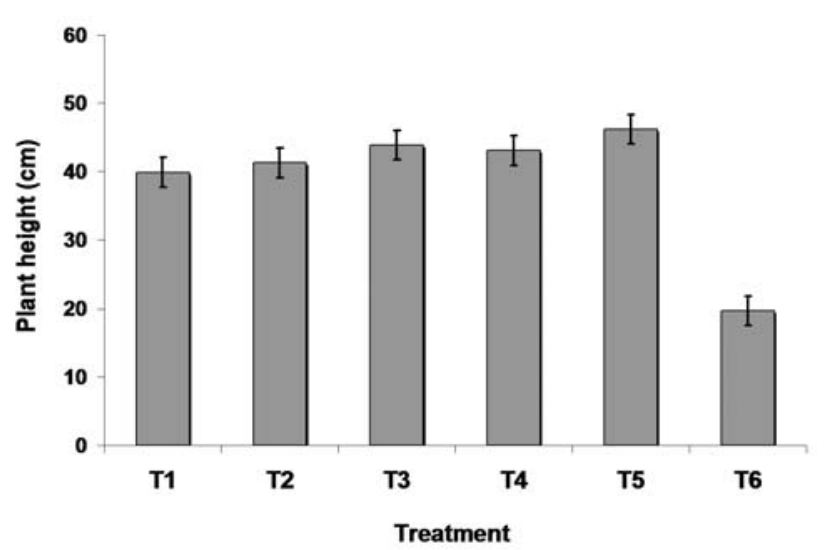

Fig. 2. Effect of different fertilizer treatments on the mean height $(\mathrm{cm})$ of cabbage (Brassica oleracea)

\section{Circumferences}

Like plant height the circumferences of cabbage plants grown on soil treated with digested CD and PL bio-slurry was significantly affected $(\mathrm{P}<0.01)$. The highest mean plant circumference was obtained from RDF $+5 \mathrm{tha}^{-1}$ digested PL bio-slurry $\left(\mathrm{T}_{5}\right)$ treated plot which was $82.7 \mathrm{~cm}$ and the lowest was obtained from native fertility (Fig. 3). PL along with RDF either fresh or digested gave better results than that of CDs. On an average, the mean circumferences of cabbage were found higher for digested cowdung and poultry litter bio-slurry treated plot (i.e. treatment $T_{3}$ and $T_{5}$ ) than the undigested cowdung and poultry litter treatment (i.e. treatment $T_{2}$ and $\left.T_{4}\right)$ which were statistically significant $(\mathrm{P}<$ $0.01)$.

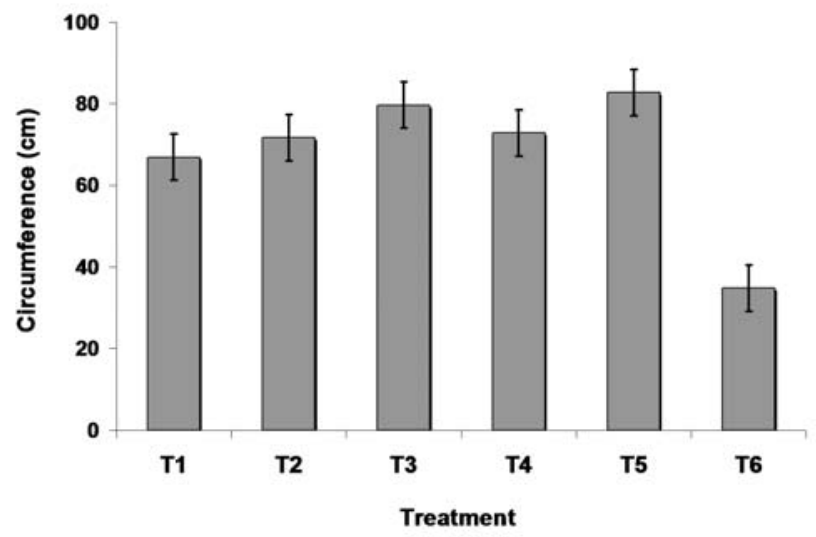

Fig. 3. Effect of different fertilizer treatments on the mean circumference $(\mathrm{cm})$ of cabbage (Brassica oleracea)

Whole plant weight and Marketable weight

Both mean marketable and whole plant weight of cabbage were relatively higher for RDF with digested CD and PL bioslurry than the RDF with undigested $\mathrm{CD}$ and PL treated plot. Significant statistical differences $(\mathrm{P}<0.01)$ in the mean marketable and whole plant weight were found for all the sources of $\mathrm{CD}$ and PL application. Both the mean whole plant weight $(3.45 \mathrm{~kg})$ as well as the mean marketable weight $(2.89 \mathrm{~kg})$ of cabbage was the highest for RDF $+5 \mathrm{t}$ $\mathrm{ha}^{-1}$ digested PL bio-slurry treatment which was closer to 
$\mathrm{RDF}+5 \mathrm{tha}^{-1}$ digested CD bio-slurry treatment where the mean whole plant weight was $3.35 \mathrm{~kg}$ and mean marketable weight was $2.78 \mathrm{~kg}$ respectively, these values were statistically different $(\mathrm{P}<0.01)$. Relatively higher mean whole

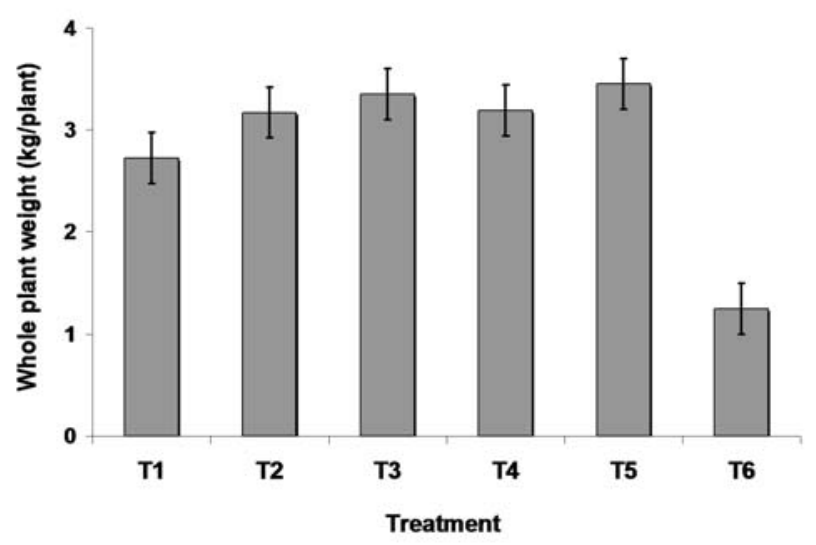

Fig. 4. Effect of different fertilizer treatments on mean whole plant weight $(\mathrm{kg})$ of cabbage (Brassica oleracea)

plant weight ( $3.19 \mathrm{~kg}$ at $\mathrm{T}_{4}$ and $3.17 \mathrm{~kg}$ at $\mathrm{T}_{2}$ ) and marketable weight $\left(2.69 \mathrm{~kg}\right.$ at $\mathrm{T}_{4}$ and $2.75 \mathrm{~kg}$ at $\left.\mathrm{T}_{2}\right)$ of cabbage were obtained with fresh CD and PL treatment $(\mathrm{P}<0.01)$ than the only soil test based inorganic fertilizer application (whole plant weight was $2.72 \mathrm{~kg}$ and marketable weight was 2.61 $\mathrm{kg})$. The lowest mean whole plant weight $(1.25 \mathrm{~kg})$ and marketable weight $(0.75 \mathrm{~kg})$ of cabbage was obtained for $\mathrm{T}_{6}$ (native fertility) treatment.

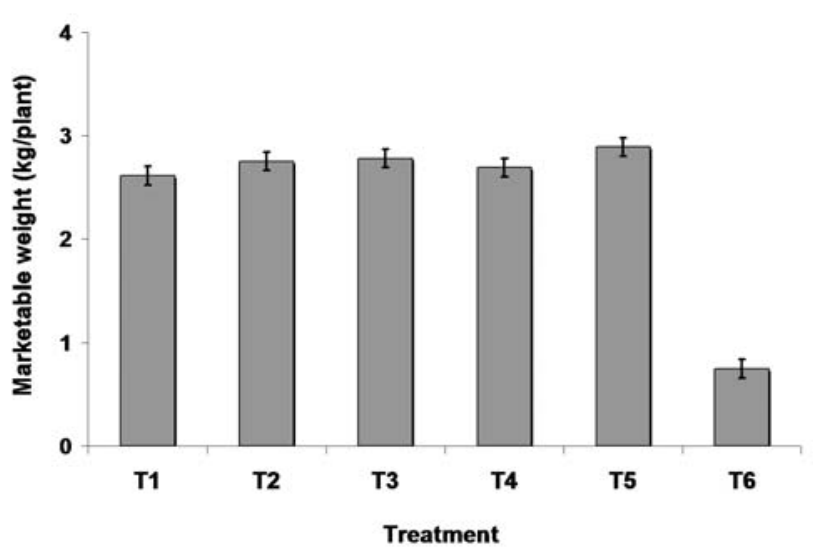

Fig. 5. Effect of different fertilizer treatments on mean marketable weight $(\mathrm{kg})$ of cabbage (Brassica oleracea)

Head yield

Obtained head yield of cabbage are expressed in $\mathrm{t} \mathrm{ha}^{-1}$ and shown in Fig. 6. Head yield of cabbage grown on soil treated with different sources of fresh and digested CD and PL were significantly affected by the materials $(\mathrm{P}<0.01)$.
Significant statistical differences $(\mathrm{P}<0.01)$ in head yield production of cabbage were observed for all the treatments (Fig. 6). Highest mean head yield of cabbage (97.6 t ha-1) was obtained from RDF $+5 \mathrm{tha}^{-1}$ digested PL bio-slurry $\left(\mathrm{T}_{5}\right)$ which was significantly different $(\mathrm{P}<0.01)$ from all the treatments. This was followed by $\mathrm{T}_{3}\left(95.7 \mathrm{tha}^{-1}\right), \mathrm{T}_{4}(87.9 \mathrm{t}$ $\left.\mathrm{ha}^{-1}\right), \mathrm{T}_{2}\left(86.9 \mathrm{t} \mathrm{ha}^{-1}\right)$ and $\mathrm{T}_{1}\left(83.3 \mathrm{t} \mathrm{ha}^{-1}\right)$ (Fig. 6). Lowest mean head yield of cabbage $20.9 \mathrm{t} \mathrm{ha}^{-1}$ was obtained from native fertility $\left(T_{6}\right)$.

About $366 \%$ yield increase of cabbage over native fertility $\left(\mathrm{T}_{6}\right)$ was recorded in $\mathrm{T}_{5}\left(\mathrm{RDF}+5 \mathrm{tha}^{-1}\right.$ digested PL bio-slurry) treatment $(\mathrm{P}<0.01)$. Yield increase of cabbage due to application of RDF $+5 \mathrm{t} \mathrm{ha}^{-1}$ digested CD bio-slurry $\left(\mathrm{T}_{2}\right)$ was $357 \%$ which was similar to yield increase for treatment $\mathrm{T}_{5}$ but significantly different $(\mathrm{P}<0.01)$ from the native fertility $\left(\mathrm{T}_{6}\right)$. Due to application of fresh PL and $\mathrm{CD}$ yield increases of cabbage were $320 \%$ and $315 \%$ respectively in comparison with native fertility which were also statistically significant $(\mathrm{P}<0.01)$. In an experiment Jayakumar et. al. (1993) found that biogas slurry at the rate of $300 \mathrm{gm}$ per pot produced the largest head of Sunflower. Manna and Hazra (1996) reported that application of biogas slurry increased cob yield of Maize. Batsai et. al. (1979) reported in an experiment that chemical fertilizer along with organic fertilizer produced the highest yield of cabbage (Brassica oleracea). The yield increases due to the incorporation of PL or CD could be related to the extra nutrients added for these sources in addition to the RDF.

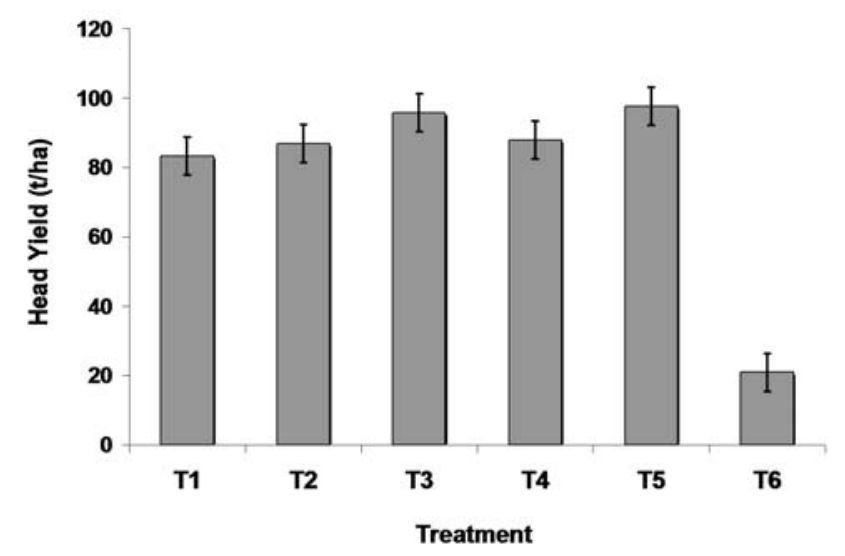

Fig. 6. Effect of different fertilizer treatments on the mean head yield $\left(\mathrm{t} \mathrm{ha}^{-1}\right)$ of cabbage (Brassica oleracea)

\section{Conclusion}

The results obtained in this field experiment revealed that amongst the four fertilizer treatments digested poultry litter (PL) bio-slurry was found to be the best for cabbage production followed by digested cowdung (CD) bio-slurry, fresh 
poultry litter (PL) and cowdung (CD) in combination with recommended dose of fertilizers (RDF). For economically profitable higher production of cabbage both poultry litter bio-slurry $\left(5 \mathrm{tha}^{-1}\right)$ and cowdung bio-slurry $\left(5 \mathrm{tha}^{-1}\right)$ after anaerobic digestion along with soil test based recommended dose of fertilizers were found better than traditionally decomposed poultry litter and cowdung.

\section{References}

APHA-AWWA-WPCF (1980), Part 300: Determination of metals. In: Standard methods for the examination of water and wastewater. 15th Ed. (American Public Health Association, NW Washington DC) 1980, pp 141-147.

BARC (2005), Fertilizer Recommendation Guide 2005. Miah, M. U. Farid, A. T. M. Miah, M. A. M. Jahiruddin, M. Rahman, S. M. K. Quayyum, M. A. Sattar, M. A. Motalib, M. A. Islam, M. F. Ahsan, M. Sultana, R. Eds. (BARC Soil Publication no. 45. ISBN: 984-32-3166-X) 2005, pp 1-260.

Batsai ST, Polyakev AA and Nedbal RF (1979), Effect of organic and mineral fertilizers on the yield and quality of irrigated late white cabbage in the steppe region of the Crimea. Hort. Abst. 49 (11): p 730.

Bhuiyan NI (1991), Issues concerning declining/stagnating productivity in Bangladesh Agriculture. A paper presented at the National Workshop on Risk Management in Bangladesh Agriculture, 24-27 August, 1991, BARC, Dhaka, Bangladesh.

Bremner JM (1996), Total Nitrogen. In: Methods of soil analysis: Part 3 Chemical methods, Eds. Sparks, D.L (SSSA and ASA Madison, Wisconsin, USA) 1996, pp 1123-1184.

Gomez KA and Gomez AA (1976), Statistical procedures for agricultural research with emphasis on rice, International Rice Research Institute, Los Banos, Philippines 1976, pp 97-104.

Guar AC, Neelaakantan S and Dargan SK (1984), Organic Manures. ICAR, New Delhi. p 75.

Helmke PA and Sparks DL (1996), Lithium, sodium, potassium, cesium and rubidium. In: Methods of soil analysis: Part 3 Chemical methods, Eds. Sparks, D.L. (SSSA and ASA Madison, W.I.) 1996, pp 551-574.

Huq SMI and Alam MD (2005), A Handbook on Analyses of Soil, Plant and Water, Eds. (BACER-DU, University of Dhaka, Dhaka, Bangladesh) 2005, pp xxii+246.
Islam MS (2006), Use of Bio-slurry as organic fertilizer in Bangladesh Agriculture. Proceedings of International Workshop on the Use of Bio-slurry, Domestic Biogas Programmes. 27-28 September 2006, Bangkok, Thiland.

Jackson ML (1962), Soil Chemical Analysis. (Prentice Hall Inc. Englewood Cliffs. N.J., USA) 1962, pp 1-498.

Jayakumar M, Eyini M and Elangovan R (1993), Effect of biogas slurry on salinity-included changes in growth and yield of Sunflower. Indian J. of Agricultural Sciences. 63 (10): 655-657.

Kuo S (1996), Phosphorus. In: Methods of soil analysis: Part 3 Chemical methods, Eds. Sparks, D.L. (SSSA and ASA Madison, W.I., USA) 1996, pp 869-920.

Manna MC and Hazra JN (1996). Comparative performance of cowdung slurry, microbial inoculum and inorganic fertilizers on Maize. J. of the Indian Soc. of Soil Science. 44: 526-528.

MoA (2003), Manual for Fertilizer Analysis, Bangladesh Agricultural Research Council (BARC), Ministry of Agriculture, GoB. 1st Ed. (Soil Publication no. 44. ISBN 984-32-1009-3) 2003, pp ix+1-76.

Robin CM (1994), Poultry manure as a fertilizer for vegetable crops. Dept. Agril. Expt. Stn. Bull. p 281.

Singh K, Gill JS and Verma OP (1970), Studies on poultry manure in relation to vegetable production. Indian. $J$. Hort. 27: 42-47.

Sparks DL (1996), Methods of soil analysis. Part 3 Chemical methods, Eds. Sparks, D.L. (SSSA and ASA Madison W.I., USA) 1996, pp 555-574.

Subhan (1991), Effect of organic materials on growth and production of cabbage (Barssica oleracea). Soils and Fert. 54 (4): 587.

Thomas GW (1996), Soil pH and soil acidity. In: Methods of soil analysis: Part 3 Chemical methods, Eds. Sparks, D.L. (SSSA and ASA Madison, W.I. USA) 1996, pp 475-490.

Ure AM (1990), Methods of analysis for heavy metals in soils. In: Heavy metals in soils, Eds. Alloway, B.J. (Blackie and Sons Limited, Glasgow) 1990, pp. 41-80.

USDA (1951), Soil Survey Manual by Soil Survey Staff, Bureau of Plant Industry. (Soil and Agricultural Engineering, Handbook No. 18) 1951, p 205.

Received: 15 March 2012; Revised: 03 September 2012; Accepted: 13 September 2012. 